\title{
THE RELATIONSHIP BETWEEN AUTOCHTHONOUS WINE ATTRIBUTES AND WINE CONSUMPTION MOTIVES
}

Anita Silvana Ilak Peršurić1, Ana Težak Damijanić ${ }^{2}$ Simon Kerma ${ }^{3}$

*Corresponding authorE-mail: anita@iptpo.hr

\begin{abstract}
A R T I C LE IN F O
A B S T R A C T

Original Article

Received: 27 November 2018

Accepted: 10 December 2018

doi:10.5937/ekoPolj1804337I

UDC 339.133.3:663.21

Keywords:

consumers, wine attributes, consumption motives, autochthonous wine

JEL: D12, Q19

This paper had a goal to explore the relationship between autochthonous wine attributes and wine consumption motives. Data were collected through a questionnaire, processed by standard statistical methods, univariate (general description of the sample), and multivariate statistics (factor analysis, cluster analysis and logistic regression). Through factor analysis five main dimensions of wine consumption motives were determined, namely social status, socializing effects, health, self indulgence and relaxation. For autohchthonous wine (Malvazija Istarska) three factor dimensions of wine attributes were determined: reccomendations, quality and origin. Through cluster analysis, wine consumption motives showed significant relations to the wine attributes, whereas selfexpression, and health and taste stood out as the most important dimensions between high and low wine attribute importance segments.
\end{abstract}

(C) 2018 EA. All rights reserved.

\section{Introduction}

Wine is a high involvement product, so it can reflect the consumers' lifestyle, sense of identity and, due to different and wide range of attributes it can "fit" to a person. Therefore, wine consumers tend to pay special attention to different wine attributes in terms of origin (Kallas et. al. 2012)(local, autochthonous versus imported wines), grape variety, chemical and sensory features (as a consequence of freshness or aged, matured wines), packaging, pricing etc.

Our research was carried out in Istria where tourists that visit Istria, and local consumers mostly consume regional autochthonous wines, such as Malvasia istarska (white), and Teran (Refošk in Slovenia), Borgonja and Hrvatica (red) (Ružić et al., 2006). Hence, the main focus was placed on Malvazija istarska as the most commonly produced wine in

1 Anita Silvana Ilak Peršurić, Ph.D., Scientific advisor, Institute for Agriculture and Tourism, C. Hugues 8, Poreč, Croatia, Phone:+38552408329, e-mail:anita@iptpo.hr

2 Ana Težak Damijanić, Ph.D., Scientific associate, Institute for Agriculture and Tourism, C. Hugues 8, Poreč, Croatia, Phone: +38552408300, e-mail:tezak@iptpo.hr

3 Simon Kerma, Ph.D., Scientific associate, Turistica, Fakulteta za tursitične sštudije, Obala 11a, Portorož, Slovenija, Phone: +3865617000, e-mail: Simon.Kerma@fts.upr.si

http://ea.bg.ac.rs 
Istria (Ilak Peršurić and Težak, 2011) and most frequently presented wine in restaurants in Istria (Težak et al., 2009). Malvazija istarska is a geographically recognized, controlled and protected wine cultivar specific for Istria as a region. It is a grape variety grown predominantly in Istria (but also in some parts of Kras/Carso, Vipava valley and Brda/ Colio). Malvasia istarska is also a wine brand well known in Croatia and Slovenia and among tourists visiting Istria, so it is a main focus of wine tourism in Istria.

As a way of promoting Malvazija istarska, different wine exhibitions and fairs are organized throughout the year in Istria because they enhance the perception of the wine region, the wine producers and their wines and overall the whole tourism destination (Ilak Peršurić et al, 2016). Wine events can be seen as a great marketing tool for wine producers and a way to attain a contact with consumers. As a producers' driven event it can be attractive to both, tourists and local-regional consumers. The consumers can get to know wine producers, taste wines and create an image about the wines. Wine events (fairs, festivals, exhibitions) are especially important for smaller wine producers with smaller quantities of wines, especially autochthonous wines, and less marketing funds and skills.

Due to the importance that wine exhibitions have in promotion of autochthonous wines, this research focuses on wine exhibition visitors. Research regarding wine attributes and wine motives is ussually concentrated on wine in general terms (Verdonk et al., 2016, Chrysodou and Jorgensen, 2016, Schultz, 2015, Cardebat and Fiquet, 2013, Jarvis et al., 2007). Our research was built upon research of Brunner and Siegrist (2011), Bruwer et al. (2002), Duarte et al. (2010), Kallas et al. (2012), MacDonald et al. (2013) and Hall et al. (2001) and Ramos et al. (2011) and explores the relationships between autochthonous wine attributes and wine consumption motives in the context of wine exhibition visitors.

\section{Theoretic background}

Consumers in Western societies usually purchase food and beverages through retailers e.g. retail chains and shops, while they are less likely to buy them directly from the producer on green markets or at the farm/cellar door.

In general terms wines have certain attributes, in literature described as extrinsic and intrinsic attributes, whereas extrinsic qualities are origin, grape variety, packaging, price, while intrinsic qualities have a value for reputation, expert opinions, tasting ratings, appellation, and sensory values.

Wine as high involvement product reflects the consumers lifestyle, sense of identity and with its wide range of offer wine as a sensory product can "fit" to a person.

Wine is a "single origin" product, with clear origin of a certain land, wine region, grape variety and therefore it can be clearly distinguished on the wine market from other products with the same name "wine".

Wines with regional features, especially wines from well-known wine regions with geographical identity, autochthonous wines and awarded wines have a better market 
position compared to wines produced in less known wine countries and regions, so those wines are an excellent base for developing wine tourism and enhancing gastronomic experience. Consumers perceive the reputation of a wine region and labels as a direct assurance of the wine quality (Combris et al., 2009, Gomez et al., 2013, Koch et al., 2013, Marzo-Navarro et al., 2012, Melo et al., 2010). Wine consumption motives also have an important role in wine purchasing decisions and they are directly linked to wine attributes (Bruwer et al., 2002, Duarte et al., 2010, Fotopoulos et al., 2003). As showed by Lockshin et al. (2006) an average consumer facing unfamiliar wines and without previous knowledge about a wine on the shelf will choose in priority the wine from a well-known region or a wine which has received a certain award or medal.

Geographic origin of a wine presumes specific qualities of the wine that can be described by analytical (chemical, physical) and sensorial features. For certain grape varieties these qualities are well known and prescribed by independent accreditation organizations or authorities which organize wine testing, tastings and ratings ensuring that the wine satisfies the criteria of geographic origin and grape variety label.

Therefore the aspect of wine region and vine variety is very important and can lead a consumer toward understanding what is in the bottle influencing the purchase and consumption. Well-known brands (advertised or recommended) also positively influence on purchase, especially on low involvement consumers while highly involved consumers chose more often something new, even from less known wine land or region because they have more knowledge and are more aware and conscious about new wines on the market (Verdonk et al., 2016). For Danish consumers the origin of wine and grape variety were most important attributes (Chrysochou and Jorgensen, 2016). Danish consumers perceived origin labels as official assurance of quality and authenticity. Labels of world wine known regions or countries such as France, Italy, Spain as "old" wine countries and Australia, Chile as "new" wine countries with heavily marketed wines can easily provoke a consumer to purchase their wine (much more than a less known land of origin like Croatia). On the case of Australian and Spanish consumers the regional and wine region label were highly valued among consumers and affected their purchase decisions (Kallas et al, 2012, Verdonk et al. 2016). Australian consumers showed their loyalty to typical Australian red wines with European origin like Cabernet Sauvignon and Shiraz (Jarvis et al. 2007). These two types of wines were most common on the Australian market and were very well accepted. Their most appreciated attribute was price, followed by grape variety, region of production and brand. The age of wine and the process of wine ripening has also an effect on the consumer's behaviour in wine consumption and purchase. Beside the wine region label, the special labels such as eco labels can achieve higher, premium prices as shown in the case of Canada (Lopes et al. 2016).

The influence of extrinsic features of the wine bottle (etiquette, label, bottle size and shape) have certain effects on the perception of wine and affect on the intrinsic description of wines such as high end, prestigious, ancient, refined, elegant, noble, with tradition, rustic, trustworthy or at the other end as modern, basic, cheap, simple, clear, modest, empty (Celhay and Remaud, 2016).

http://ea.bg.ac.rs 
According to wine types there is a general impression that consumers like more fresh white wines and consume less frequently sparkling or sweet wines (Melo et al., 2010). Also aged wines are accepted as wines with more value (Hughson et al., 2004, Chrea et al., 2011) especially red wines. Chinese consumers too, tend to favour red Australian wines (Liu and Murphy, 2007). They developed various ideas that the consumption of red wine is connected to certain "higher", "classier" life style. In the case of white wines, Australian consumers place high loyalty on fresh Chardonnay and Riesling (European origin grapes) which were most common white wines on the Australian market (Jarvis et al., 2003).

Classification of consumers in surveys holds to overall suggestions that price and grape variety have the strongest influence on consumers' choice and purchase, while packaging and labels were ofless importance. Consumers tend to reflect the price to the level of quality and are willing to pay higher price for wines from well-known wine regions (Ampuero and Villa, 2006, Boudreaux and Palmer, 2007, Chrea et al., 2011). The importance of price per bottle is rooted in the intrinsic value of the consumer and therefore can achieve "hedonic" price (Frankel and Rose, 2010, Rössel and Beckert, 2012).

When purchasing a wine for the first time, the consumer often has no previous knowledge about the product or that knowledge is limited, so the consumer has to rely on different wine attributes. Wine is perceived as a product which has a certain value. This value is perceived before the product is consumed, which means that consumers decide on the purchase primarily through the extrinsic features such as geographic origin, grape variety, harvesting year. When the wine is purchased and consumed (benefits received) then the consumer can be motivated for purchase with intrinsic attributes which rely more to their emotional response and beliefs. Satisfaction (e.g. "good value for money") or dissatisfaction with the product stored in the consumers' memory can affect the future consumption or purchase (Foxall and Goldsmith, 1994). Wine attributes have been studied by various researchers in different contexts like quality (Combris et al., 2009, Gomez et al., 2013, Koch et al., 2013, Marzo-Navarro et al., 2012, Melo et al., 2010), perception of wine (Celhay and Remaud, 2016), loyalty (Jarvis et al., 2007), lifestyle (Bruwer et al., 2002), relevance (Eldesonky and Mesias, 2014), wine quality (through dimensions of extrinsic values such as origin, vintage and ageing ability and intrinsic attributes, like flavour, bouquet, image, Jouvier et al. (2004).

Generally speaking, wine attributes enable producers to position their wines on the market, and help consumers in making wine purchasing decisions. Matos Graça Ramos et al. (2011) found that consumers perceive wine attributes as intrinsic and extrinsic and that those attributes are either tangible or intangible. Thus, extrinsic and intrinsic attributes of wine as a product are usually a starting point for researcher interested in examining wine attributes.

Wine attributes were examined by a number of authors, whereas extrinsic attributes were origin, grape variety, packaging, price, while intrinsic attributes were value for reputation, expert opinions, tasting ratings, appellation, and sensory values (Chrysochou and Jorgensen, 2016, Eldesonky and Mesias, 2014, Matos Graça Ramos et al., 2011). 
In the context of visibility Eldesonky and Mesias (2014) determined that package is the main attribute to achieve it, the shape, colour, size, letters, pictures, information (weight, calories, expiration date, content, product description) on the bottle are as relevant as the price, quality, brand, origin of the wine.

Consumers tend to link the price to the quality level of the wine and are willing to pay higher price for wines from well-known wine regions (Ampuero and Villa, 2006, Boudreaux and Palmer, 2007, Chrea et al., 2011). Those regions usually develop wellknown brands (advertised or recommended) that have positive influence on purchase, especially in the case of low involvement consumers (Verdonk et al., 2016) or consumer that have no knowledge about the wine (Lockshin et al., 2006).

The age of wine and the process of wine ripening have also an effect on the consumer's behaviour in wine consumption and purchase. According to wine types there is a general impression that consumers like more fresh white wines and consume less frequently sparkling or sweet wines (Melo et al., 2010). Also aged wines are accepted as wines with more value (Hughson et al., 2004, Chrea et al., 2011) especially if they are red wines. In the case Australian consumers high loyalty levels were evident to Chardonnay and Riesling (European origin grapes) which were most common on the market (Jarvis et al., 2007).

The influence of extrinsic features of the wine bottle (etiquette, label, bottle size and shape) have certain effects on the perception of wine and effect the intrinsic description of wines such as high end, prestigious, ancient, refined, elegant, noble, with tradition, rustic, trustworthy or at the other end as modern, basic, cheap, simple, clear, modest, empty (Celhay and Remaud, 2016). Reputation of a wine region for consumers directly assures quality of the wine (Combris et al., 2009, Gomez et al., 2013, Koch et al., 2013; Marzo-Navarro et al., 2012, Melo et al., 2010). Another social influence on consumers occurs though recognition and positive recommendations from experts, such as sommeliers and catering facilities personnel. When ,wine experts“ review certain wine attributes positively and publish the findings of wine reviews in report or articles, those reviews have positive effects on wine procurement (Hertzberg and Malorgio, 2008, Roma et al., 2013). Wines with positively rated sensory attributes can achieve ,hedonic,, price of wine (Benfrattelo et al., 2009, Cardebat and Fiquet, 2009, 2013, Outreville, 2011). The opinions of experts and retailers are welcome as they enhance the purchase (Cardebat and Fiquet, 2013). In the case of retailers, the educated and knowledgeable personnel who can give recommendations about wines are highly valued by consumers and enhance the sales (Goodman et al., 2010).

While wine attributes influence consumer's choices, wine consumption motivations as inner drives cause people to take actions to satisfy their needs (Hughson et al, 2004). When considering reasons why consumers drink wine, various, often different motives emerge (Brunner and Siegrist, 2011, Charters, 2006, Duarte et al., 2010, Fotopoulos et al., 2003, Hall et al., 1997). Based on previous research regarding wine consumption motives, Charters (2006) divided wine consumption motives into three main groups, namely 
physical or utilitarian reasons (like refreshment and improvement of health), experiential in character or hedonic reasons (e.g. relaxation, socialization trying something new), and symbolic reasons (like social acceptance and celebration). These three groups summarise different research where different wine consumption motives were determined like motives linked to product features, social factors and psychological dimensions (Hall et al., 1997); motives related to food's attractiveness, good taste, quality, healthiness, information/control/ethical production, traditional image and distinctiveness (Fotopoulos et al., 2003), different motives related to lifestyle (Brunner and Siegrist, 2011) and other wine consumption motives and attitudes (Duarte et al., 2010).

Wine consumption motives influence wine purchasing and are important in relation to wine attributes (Brunner and Siegrist 2011, Bruwer et al. 2002, Duarte et al. 2010, Fotopoulos et al, 2003, Liu and Murphy 2007). The relationships between wine consumption motives and wine attributes were examined by Brunner and Siegrist (2011) with similar approach to Bruwer et al. (2002) and combined involvement, motives and attributes in order to detect consumer oriented segments for the Swiss wine market. Duarte et al. (2010) examined this relationship using a more direct approach i.e. they linked the segments of wine consumers based on the wine consumption motives with miscellaneous intrinsic and extrinsic wine attributes.

The relationship between wine consumption motives and wine attributes is usually examined indirectly (Brunner and Siegrist, 2011, Bruwer et al. 2002, Fotopoulos et al. 2003, Liu and Murphy, 2007). Bruwer et al. (2002) included wine consumption motivations through dimensions of wine-related lifestyle and they determined differences between consumers on the basis of wine style and price. Fotopoulos et al. (2003) examined this relationship by grouping motives into different groups of consequences and values (i.e. functional consequences, psychological consequences, instrumental values and terminal values) and then liking them though hierarchical value map with wine attributes (label, bottle, value for money, origin etc.).

\section{Materials and methods}

\section{Research settings}

Primary research was conducted as a part of project financed by Operational Programme Slovenia-Croatia 2007-2013, "MalvasiaTourIstra" thus it included both the Croatian and Slovenian part of Istria. Every year from March through November many wine fairs and exhibitions in Istria take place, mainly in order to stimulate and promote wine as a part of gastronomy offer and Istria as a wine region. The main focus of this research was placed on two wine exhibitions (wine exhibition Vinistra in Poreč, Croatia and wine exhibition Festival Malvazija in Portorož, Slovenia). Both wine exhibitions place high importance on wine Malvazija istarska, which is autochthonous to the region. The wine exibition Vinistra is organized each May by the Wine and Viticulture Association - Vinistra, Town of Poreč and Istria County, while Festival Malvazija is organized by the Association of Wine Growers in Slovenian Istra and by the Town of Portorož. Both 
exhibitions comprise also various accompanying evens, like food and wine pairing, cooking shows, presentations of wines and producers, presentation of wine accessories (glasses and bottles special for Malvazija tasting and bottling), professional speakers with presentations about Malvazija (production, marketing, wine tourism etc.). Both wine fairs and organizers are active on their national and international level to promote Malvazija istarska as a brand, a geographically recognized, controlled, protected wine cultivar specific for Istria as a region. Vinistra organizes contests and ratings for the best Malvasias ("The world of Malvazija" whereas all producers from all over the world can apply with Malvazija, because beside Malvazija Istarska which is grown only in Istria, there exist about five hundred varieties of Malvazija grown in other European and overseas countries). Similarly in Slovenia a contest for the best Malvazija is organized.

All these activities have influenced positively on the image of Malvazija istarska as a wine and on Istria as a wine region, and finally enhanced the picture of Istria as a tourism destination.

In order to analyze the behavior of wine exhibition visitors, their motives for wine consumption, preferences to wine attributes and the correlation of these two research subjects, we have chosen a sample of visitors which attended two wine fairs.

Our intention was to collect as much data as we could (this was the first scientific research of this type in both countries) about the consumer behavior considering one autochthonous wine (and grape) variety, Malvazija istarska.

Since in literature the vast research is forwarded to wine in general terms, in our research we had used a relatively rare approach to study one recognized, geographically protected and autochthonous variety. Somehow we have followed the research of other authors (Verdonk et al., 2016, Chrysodou and Jorgensen, 2016, Schultz, 2015, Cardebat and Fiquet, 2013, Jarvis et al., 2007) and tried to examine if regional/local attributes are rated and appreciated by consumers (similar to the case of Spain, Kallas et. al. 2012., whereas the regional attribute of "Catalan" was rated higher that the attribute "Spain" in general population, and pointed stronger by high involvement wine consumers).

The purpose of this paper was to explore the relationship between autochthonous wine attributes and wine consumption motives in the context of wine exhibition visitors. The goals of this paper were threefold: 1) to determine dimensions of wine consumption motives and wine attributes in the context of wine exhibition visitors; 2) to classify wine exhibition visitors based on the wine attributes related to autochthonous wine Malvazija Istarska; and 3) to determine relationship between wine attributes and wine consumption motives.

\section{Sampling}

The research study was conducted in Croatia in May 2014. while in Slovenia in March 2015. The target population included visitors of two wine exhibitions (Festival Malvazija and Vinistra) who were 18 years of age or older. They visited only the first or 
the second wine exhibition. Visitors were approached by trained researchers and asked to participate in the survey. Researchers explained the purpose of the survey and said that the survey was anonymous. In the process of on-site data collection researchers were stationary while responders were mobile (Veal, 2006) and a convenient sample was used. The self-complete questionnaires were administered by researchers and 244 validated questionnaires were collected (the requirements for performing exploratory factor analysis were satisfied - a minimum number of 150 according to Field, 2005, Hair et al., 2014, Hinkin et al., 1997).

\section{Measurement}

For the purpose of this study, wine consumption motives and wine attributes were defined as multidimensional constructs. Wine consumption motives were adopted from Brunner and Siegrist (2011), Duarte et al. (2010), MacDonald et al. (2013) and Hall et al. (2001). In all, 33 items were originally used for measuring dimensions of wine consumption motives. Wine attributes were adopted from Duarte et al. (2010), MacDonald et al. (2013), Corduas et al. (2013), Quester and Smart (1996), Hall et al. (2001) and Ramos et al. (2011).

Our first hypothesis was that wine consumption (of Malvazia Istarska) would be motivated by social and socializing motives. The second hypothesis presumed that wine (of Malvazia Istarska) will be perceived as a healthy product and mean of relaxation. In our third hypothesis we presumed that attributes of origin and quality will be ranked as highest (for Malvazia Istarska wine). Our final hypothesis comprised the first three and presumed that wine attributes and consumption motives are connected with a statistically strong connection.

A total of 14 items were used for measuring wine attributes of Malvazija Istarska as an autochthonous wine to Istria region. Wine consumption motives and wine attributes were measured using a five-point Likert scale (1 = "strongly disagree" to 5 = "strongly agree").

For the purpose of gathering data the questionnaire was constructed. It consisted of 23 questions which were divided into four sections: 1) preferences about wine consumption and purchase in general, 2) questions related to Malvazija Istarska as a autochthonous Istrian wine, 3) question focused on certain aspects of wine exhibition and 4) respondents' socio demographic characteristics (age, gender, education level, occupation, net monthly personal income and town/municipality). It was originally designed in Croatian and then translated into Slovenian by bilingual associate.

\section{Statistical analysis}

Data were processed using univariate and multivariate statistics. Univariate statistics were used for general description of the sample while multivariate statistics were used for determining dimensions of wine consumption motives and wine attributes, segmentation based on wine attributes and testing relationship among wine consumption motives and wine attributes. 
To determine dimensions of wine consumption motives and wine attributes, exploratory factor analysis was done using maximum likelihood method and promax rotation with an eigenvalue of 1.00 or more to identify potential factors. Internal reliability for the scales was determined by computing Cronbach's alpha. Dimensions of lifestyle were calculated as a mean value for each respondent (DiStefano et al., 2009).

Cluster analysis was used for segmenting wine exhibition visitors based on the level of importance they place on different wine attributes for autochthonous wines. The number of clusters was determined by splitting the sample and using hierarchical clustering technique. Fifty observations from the sample were randomly selected for the hierarchical cluster analysis. The Ward method with squared Euclidean distance was employed to establish the preliminary number of clusters. To substantiate the number of clusters, nonhierarchical clustering technique (k-means) was used. Identified clusters were named using cluster centroids. Cluster validation using t-test for the purpose of criterion validity used six measures that were not included in the previous analyses (Hair et. al., 2014).

In order to determine the relationship between wine attributes and wine consumption motives, logistic regression was used. Dependent variable was two-cluster solution obtained through segmentation of importance of wine attributes for autochthonous wines of wine exhibition visitors. Independent variables were dimensions of wine consumption motivation.

\section{Research results}

\section{Descriptive statistics}

In total, questionnaires from 244 respondents were used in the analysis (45\% Festival Malvazija and 55\% Vinistra). The proportion of male respondents (58\%) was slightly higher than that of females (42\%). The majority of respondents were between 18 and 34 years of age (56\%). The majority had obtained higher education (60\%). According to employment, the respondents were self-employed (36\%), 29\% were employees, approximately $13 \%$ were students and $11 \%$ were retired. Visitors of Vinistra were in majority from Istria region (mostly from Poreč (12\%), Pula (8\%) and Portorož (6\%) and $2 \%$ of foreign visitors, while visitors of "Festival Malvazija" were too in majority from Istria region with a slightly higher percentage of visitors outside the region Istria (10\% from either Maribor or Ljubljana). Over 50\% of the respondents came to wine exhibitions with their friends and two-thirds have already attended one of the wine exhibitions. Visitors usually visit either one (39\%) or two (25\%) wine exhibitions annually. In general terms they usually drink Malvazija Istarska a few times a month (38\%).

\section{Exploratory factor analysis}

To identify dimensions of wine consumption motives, exploratory factor analysis was done on 33 items representing dimensions of wine consumption motives. The item means (Table 1) varied from 2.59 ("To establish status") to 4.31 ("To complete gastronomic experience"). In general, the items measuring dimensions of wine consumption motives were mostly 
important to responders. Items with loading below .04 and cross-loadings were deleted, resulting in retention of 29 items. Using eigenvalues greater than 1.0 as criteria, five factors representing wine consumption motives formed clear factor structures (Table 2). Jointly, they accounted for $64.04 \%$ of accumulated variance, and most of the factor loading were greater than .60. They were labelled self-expression, connection, health and taste, indulgence, and relaxation. Cronbach's alpha coefficients were between .853 and .942 .

Social status and prestige was comprised of different items related to respect, sophistication, status, distinctiveness, etc. Items measuring this dimension were unimportant to respondents or the least important which is in accordance to the findings of Hall et al. (1997). Connection encompassed various items regarding interactions with others through linking food, wine and special events. Health and taste included health-related aspects, taste and aroma. Both groups of wine consumption motives were highly important to respondents. Self-indulgence was composed of items referring to positive feelings, time for oneself, learning new things, etc. Relaxation was focused on relaxation and mood improvement. These two dimensions were of middle importance to respondents. These findings are partially in accordance with the finding by Hall et al. (1997) and Fotopoulos et al. (2003). The structure of five dimensions is very similar to the proposal by Duarte et al. (2010); self-expression being a part of the symbolic reasons group, health and taste the utilitarian reasons, and indulgence and relaxation the hedonic reasons. The only difference is evident in the dimension labelled connection because the dimension contained items from two groups, namely hedonic and symbolic reasons. Our factors were similar to the findings of Charters and Ali Knight (2002) which found motives to taste wine in socializing and self-indulgence effects (on a sample of wine tourists in wine cellars).

Our factor analysis showed five factors of motives toward wine consumption of Malvazija Istarska highly saturating the matrix. The first factor Social status and prestige had eight variables all highly saturating the matrix (six were above 0.8). Our respondents were motivated to consume wine as a product which requires respect for the person who consumes it (0.889), respect from other and reflects a picture of a person that is sophisticated (0.871), mature (0.853) and successful in business $(0.840)$. Wine consumption clearly defines a person from "the others" reflecting a certain distinctiveness $(0.815)$ and status $(0.825)$. Wine is considered a modern drink (0.693) and knowledge about wine can be used to impress others (0.670).

The second factor Socializing effects related to motivation of enjoying personal connections and social occasions explaining sharing special moments in life with a bottle of wine (0.937) and connecting family $(0.786)$ in used in socializing occasions (0.762). Since such socializing occasions occur with certain food it completes the gastronomy experience (0.740) and the taste of food (0.514).

The third factor was named "Health motives and taste" whereas motives were related to positive health aspects $(0.840)$ and part of general healthy life style $(0.819)$ and natural features $(0.743)$. Taste and smell $(0.436)$ and pleasure in wine $(0.429)$ were also important motives. 
Table 1. Results of exploratory factor analysis for motives of Malvazija Istarska wine consumption

\begin{tabular}{|c|c|c|c|c|c|c|c|}
\hline Variables & 1 & 2 & 3 & 4 & 5 & Mean & SD \\
\hline \multicolumn{8}{|l|}{ Social status and prestige } \\
\hline To be respected & .889 & & & & & 2.63 & 1.463 \\
\hline $\begin{array}{l}\text { It marks a sophisticated } \\
\text { person }\end{array}$ & .871 & & & & & 2.94 & 1.454 \\
\hline $\begin{array}{l}\text { Drinking wine testifies to a } \\
\text { mature personality }\end{array}$ & .853 & & & & & 3.03 & 1.462 \\
\hline $\begin{array}{l}\text { Display of success in } \\
\text { business environment }\end{array}$ & .840 & & & & & 2.86 & 1.350 \\
\hline To establish status & .829 & & & & & 2.59 & 1.438 \\
\hline To be distinctive & .815 & & & & & 2.61 & 1.518 \\
\hline It is "in" & .693 & & & & & 2.60 & 1.539 \\
\hline $\begin{array}{l}\text { To impress other people with } \\
\text { knowledge about wine }\end{array}$ & .670 & & & & & 3.13 & 1.447 \\
\hline \multicolumn{8}{|l|}{ Socializing effects } \\
\hline $\begin{array}{l}\text { Connection during special } \\
\text { moment in life }\end{array}$ & & .937 & & & & 4.08 & 1.052 \\
\hline $\begin{array}{l}\text { Connects family across } \\
\text { generations }\end{array}$ & & .786 & & & & 3.70 & 1.220 \\
\hline $\begin{array}{l}\text { Socializing with friends and } \\
\text { family }\end{array}$ & & .762 & & & & 4.09 & 1.054 \\
\hline $\begin{array}{l}\text { To complete gastronomic } \\
\text { experience }\end{array}$ & & .740 & & & & 4.31 & 0.950 \\
\hline To enhance the taste of food & & .514 & & & & 4.25 & 0.972 \\
\hline \multicolumn{8}{|l|}{ Health motives and taste } \\
\hline Good health-related aspects & & & .840 & & & 3.82 & 1.069 \\
\hline It is a part of healthy lifestyle & & & .819 & & & 3.50 & 1.195 \\
\hline It is a natural drink & & & .743 & & & 4.03 & 1.083 \\
\hline I love the taste and smell & & & .436 & & & 4.21 & 1.027 \\
\hline Drinking for pleasure & & & .429 & & & 4.18 & 1.049 \\
\hline \multicolumn{8}{|l|}{ Self indulgence } \\
\hline To feel good & & & & .863 & & 3.88 & 1.166 \\
\hline Time for me & & & & .853 & & 3.73 & 1.260 \\
\hline $\begin{array}{l}\text { To relax after a busy } \\
\text { workday }\end{array}$ & & & & .729 & & 3.61 & 1.283 \\
\hline Trying something new & & & & .545 & & 3.74 & 1.307 \\
\hline \multicolumn{8}{|l|}{ Relaxation } \\
\hline To relax & & & & & .854 & 3.91 & 1.170 \\
\hline $\begin{array}{l}\text { To have a break in dynamic } \\
\text { environment }\end{array}$ & & & & & .786 & 3.73 & 1.262 \\
\hline It improves my mood & & & & & .717 & 3.90 & 1.173 \\
\hline Eigenvalues & 9.395 & 3.283 & 1.5468 & 1.346 & 1.000 & & \\
\hline$\%$ cumulative variance & 37.981 & 51.512 & 58.099 & 62.100 & 65.042 & & \\
\hline
\end{tabular}




\begin{tabular}{|l|c|c|c|c|c|c|c|}
\hline Variables & $\mathbf{1}$ & $\mathbf{2}$ & $\mathbf{3}$ & $\mathbf{4}$ & $\mathbf{5}$ & Mean & SD \\
\hline Cronbach's $\alpha$ & .942 & .868 & .853 & .866 & .881 & & \\
\hline Mean & 2.80 & 4.08 & 3.95 & 3.74 & 3.85 & & \\
\hline SD & 1.230 & 0.853 & 0.861 & 1.060 & 1.081 & & \\
\hline
\end{tabular}

Source: Data processed by authors

The fourth factor Self indulgence was named for motives which create pleasure for oneself, to well-being, feeling good (0.863), free time for thy self (0.853), relaxing after work (0.729) enjoy free time, creating a break in a hectic life (0.786).

The last, fifth factor Relaxation showed the need for relax in general terms and using a glass of wine to relax (0.854), dividing the day of work or other obligations and taking a break (0.786) for thyself and a mean to enhance your mood $(0.717)$.

To identify dimensions of Malvazija Istarska wine attributes, exploratory factor analysis was done on 14 items representing dimensions of wine attributes (Table 2).

Table 2. Results of exploratory factor analysis for Malvazija Istarska wine attributes

\begin{tabular}{|l|c|c|c|c|c|}
\hline Variables & $\mathbf{1}$ & $\mathbf{2}$ & $\mathbf{3}$ & Mean & SD \\
\hline Recommendations & .929 & & & 3.23 & 1.207 \\
\hline Recommendations of the salesperson & .798 & & & 3.36 & 1.104 \\
\hline Recommendations of the waiters & .591 & & & 3.44 & 1.117 \\
\hline The design of the bottle and the label & .503 & & & 3.81 & 0.986 \\
\hline Recommendations of friends & & .978 & & 3.61 & 1.086 \\
\hline Quality & & .782 & & 3.68 & 1.133 \\
\hline Ageing of wine & & .578 & & 4.00 & 1.033 \\
\hline Vintage & & .529 & & 3.64 & 1.047 \\
\hline Quality (PDO. PGI labels) & & & & \\
\hline Amount of sugar & & & .945 & 3.52 & 1.202 \\
\hline Origin & & & .913 & 3.50 & 1.224 \\
\hline Terroir / locality & & & .544 & 3.59 & 1.204 \\
\hline Micro region / wine region & & & & \\
\hline Producer/brand & 3.760 & 1.585 & 1.111 & & \\
\hline Eigenvalues & 34.180 & 48.586 & 58.685 & & \\
\hline$\%$ cumulative variance & .803 & .807 & .840 & & \\
\hline Cronbach's $\alpha$ & 3.46 & 3.73 & 3.54 & & \\
\hline Mean & .877 & .856 & 1.052 & & \\
\hline SD & & & & \\
\hline
\end{tabular}

Source: Data processed by authors

The item means varied from 3.23 (Recommendations of the salesperson) to 4.00 (Quality). All items measuring dimensions of wine attributes were important to responders to a certain degree, which is partially in accordance to the findings 
of Eldosonky and Mesias (2014) who have found that the label on the bottles is as important as quality, brand and origin. Items with loading below .04 and cross-loadings were deleted, resulting in retention of 11 items. Using eigenvalues greater than 1.0 as criteria, three factors representing wine attributes formed clear factor structures (Table 2). Jointly, they accounted for $58.69 \%$ of accumulated variance, and most of the factor loading were greater than .60. They were labelled presentation, quality and origin. Cronbach's alpha coefficients were between .803 and .840 .

Dimensions of wine attributes were calculated as a mean value for each respondent. The mean scores of the dimensions were around 3.50 with quality being the most important wine attribute. The dimensions were cluster analysed. Using the hierarchical clustering technique, two cluster solutions were selected based on the largest and most plausible proportionate change. A non-hierarchical cluster analysis procedure was utilized to finalize the cluster solutions using the a priori number of clusters determined through hierarchical technique. The latter procedure confirmed a two-cluster solution.

The results of factor analysis of motives for Malvazija Istarska wine attributes showed that we gained three factors which highly saturated the matrix. Recommendations were comprised of different aspects related to presentation of wine like recommendation, and design of the bottle and the label. In our sample these attributes scored lowest mean values, but the items were the least important to responders, similar to Cardebat and Fiquet (2013). Within the first factor Recommendations we had recommendations of the sales persons (in our case the producers at the wine fair) with the highest factor loading (0.927). Similar importance of sales staff in retail was shown by Goodman et al. in 2010. Recommendations from waiters had second importance (in restaurants or hotels) whereas respondents value very highly their opinion and influence on their choices (0.798) likewise in the case of French consumers (Cardebat and Fiquet, 2013). Since the majority of respondents came to wine fair with friend, they have valued their recommendation of wines with a high score $(0.503)$ in the first factor. Here there exists a socialising effect connected to wine as showed by Yuan and Jang (2008).

Quality included items regarding the wine properties, e.g., vintage and markers of quality. Responders found items measuring product quality of the highest importance which is partially supported by Hughson et al. (2004), Jouvier et al. (2004) and Chrea et al. (2011). Origin was composed of items referring to location of vineyards and branding. Item measuring had medium importance to responders was in accordance with the findings Comris et al, 2009 and Verdonk (2016). The reputation of Malvazija Istarska and Istria as a wine region was clearly recognized and validated by our respondents similar to findings of African, Spanish, and Australian respondents (Verdonk et al. 2016, Kallas et al. 2012, Lopes et al. 2016).

In the second factor Quality were explained; intrinsic attributes of wine ageing and vintage had high factor loadings $(0.978$ and 0.782$)$. The age of wine and its ageing process were very important to respondents because aged wines were perceived with higher value similar to findings of Hugson et al. 2004. 
Quality labels had somewhat lower loadings (0.578) since Malvazija Istarska is already an established wine with warranty of origin, production techniques and sensory qualities. Since Croatian and Slovenian consumers prefer dry and fresh wines the sugar content was of least important wine attribute in factor two (0.529).

The third and last factor comprised Origin, specific aspects of Istria as a wine region with localities (terroirs) with specific soil, climate and natural features and various producers/brands. Factor loadings showed high scores for terroir (0.945) and micro region (0.913) showing that Croatian and Slovenian consumers recognize Istria as a wine region and highly respect and recognize certain micro locations (in the Croatian part of Istria three sub regions exist). Certain localities (terroirs') were graded higher than others because they had higher value for viticulture production (because of micro climate, soil, sun insolation or exposition to sun) resulting in wines with specific recognizable sensorial features. The name of producer of the brand was the last variable in the factor matrix with loading 0.544 showing that respondents have specific taste and prefer certain producers' more than others. Therefore the family name, the story about the family, vineyards, wine and production can positively influence on the perception of the consumer and provoke them in a positive way to consume and buy Malvazija Istarska from a certain producer and certain terroir.

\section{Cluster analysis}

Cluster 1 represented $35.4 \%$ of respondents, while Cluster 2 included $64.6 \%$ of respondents. Although the two clusters differed statistically based on all three composite measures (Table 3), origin stood out. The first cluster was labelled low importance, while the second cluster was labelled high importance. The former cluster expressed unimportance of origin compared with the latter cluster.

Table 3. Results of cluster analysis

\begin{tabular}{|l|c|c|c|c|}
\hline \multirow{2}{*}{ Composite variables } & \multicolumn{2}{|c|}{ Final Cluster Centers } & \multirow{2}{*}{ F value } & \multirow{2}{*}{ Sig. } \\
\cline { 2 - 3 } & 1 & 2 & & .000 \\
\hline Recommendations & 3.00 & 3.71 & 35.061 & .000 \\
\hline Quality & 3.20 & 4.03 & 52.788 & .000 \\
\hline Origin & 2.43 & 4.14 & 297.724 & \\
\hline
\end{tabular}

Source: Data processed by authors

The second cluster in general placed high importance on three dimensions of wine attributes for autochthonous wines. Thus, origin proved to be the main differentiating aspect confirming the finding of Duarte et al. (2010) and partially confirming the findings of Chrysochou and Jorgensen (2016).

Four measures that were not included in previous analysis were used to validate clusters (Sinclair-Maragh et al. 2015). They were: awards, price, discounts and reviews. These wine attributes are usually perceived as very important attributes (Hertzberg and 
Malorgio, 2008, Roma et al. 2013) and are usually linked to each other and to other wine attributes (Benfrattelo et al., 2009, Cardebat and Fiquet, 2009, 2013, Outreville, 2011) so they were used for validation of the clusters. All four variables were significant verifying statistical differences between the cluster, thus providing support for criterion validity of the items that measured wine attributes (Table 4).

Table 4. T-test results for cluster validation

\begin{tabular}{|l|c|c|c|c|c|c|}
\hline \multirow{3}{*}{ Variables } & \multicolumn{2}{|c|}{$\begin{array}{c}\text { Cluster 1 } \\
\text { Low importance } \\
\text { 35.38\% }\end{array}$} & \multicolumn{2}{c|}{$\begin{array}{c}\text { Cluster 2 } \\
\text { High importance } \\
\text { 64.62\% }\end{array}$} & \multirow{2}{*}{ T-test } & \multirow{2}{*}{ Sig. } \\
\cline { 2 - 5 } & $\mathbf{M}$ & SD & M & SD & & \\
\hline Awards & 3.24 & 1.209 & 3.98 & 0.980 & -4.393 & .000 \\
\hline Price & 3.33 & 1.121 & 3.75 & 1.043 & -2.577 & .011 \\
\hline Discounts & 2.78 & 1.327 & 3.32 & 1.250 & -2.795 & .006 \\
\hline Reviews & 2.30 & 1.115 & 3.22 & 1.186 & -6.237 & .000 \\
\hline
\end{tabular}

Source: Data processed by authors

\section{Logistic regression}

Two predictors were significant in predicting the odds of belonging to a high importance group (Table 5). The model explained between 22 and 30\% of variance. Wine consumption motives that were significant in predicting high importance group were self-expression, and health and taste.

Table 5. Results of logistic regression

\begin{tabular}{|l|c|c|c|}
\hline Variables & B & SE & Z values \\
\hline Self-expression & $.685^{* * *}$ & .171 & 4.010 \\
\hline Connection & -.144 & .254 & -0.566 \\
\hline Health and taste & $.738^{* *}$ & .270 & 2.732 \\
\hline Indulgence & .351 & .227 & 1.546 \\
\hline Relaxation & -.364 & .230 & -1.578 \\
\hline Constant & $-3.388^{* *}$ & 1.042 & \\
\hline
\end{tabular}

Source: Data processed by authors

Note: Cox \& Snell R Square $=0.216$, Nagelkerke R Square $=0.296, * * * \alpha$ significant at 0.001 , ** $\alpha$ significant at $0.01, * \alpha$ significant at 0.05

Both motives increased the odds of being in a high importance group suggesting that those two motives are more important to responders who place higher importance on wine attributes when buying autochthonous wine.

\section{Discussion and conclusion}

This paper explored the relationship between autochthonous wine attributes and wine consumption motives in the context of wine exhibition visitors. Through the analysis, a few main implications emerged. 
Our research was based on a rare approach to study consumers and their behaviour towards an geographically protected and autochthonous wine grape and wine Malvazija Istarska. Our goal was to find what drives consumers to this particular wine similar to research of Boudreaux and Palmer on Cabernet (2007) and Cardebat and Fiquet on Beaujolas and Bordeaux wines $(2009,2013)$.

Through our research we have confirmed our first hypothesis that consumption of wine will be motivated by social and socializing motives. The structure of wine consumption motives in our sample was very similar to the proposal by Duarte et al. (2010) and Hall et al. (1997). Motives were found in expression of social status (respect, sophistication, success, distinctiveness) similar to findings of Brunner et al (2011) and Charters (2006), Fotopoulus et al (2003), Liu and Murphy (2007). Socializing effects (connection of wine with special moments, family, friends, gastronomy) were in accordance with the findings by Hall et al. (1997) whereas wine has proven as bound and connection in socializing with family and friends.

In our second hypothesis we presumed that consumers perceive Malvazija Istarska wine as a product good for their health and a mean of relaxation. We found that healthiness of the Malvazija istarska wine and its taste were generally important as wine consumption motives. Indulgence and relaxation as the purely hedonic reasons were also important consumption motives, and these findings were partially in accordance with the findings by Hall et al. (1997), Hall et al. (2001) and Fotopoulos et al. (2003).

Considering the importance of wine attributes for Malvasia Istarska as an autochthonous wine, wine exhibition visitors recognised all wine attributes as important to a certain degree, which is partially in accordance with the findings of Eldosonky and Mesias (2014). Still, a socializing effect was shown whereas friends affect wine choices of respondents more strongly than recommendations from professionals. The aspects of quality concerned age, vintage, geographic origin labels and sugar content of Malvazija Istarska, and all attributes were graded highly by respondents (similar to findings of Hertzberg and Malorgio, 2008, Matos Graca Ramos et al 2011). Origin had medium importance, suggesting that respondents were already familiar with the wine and therefore less under the influence of wine professionals opinions while more confident on their own opinions or friends recommendations. Malvazija Istarska was already positioned in their minds as an autochthonous wine of Istria as a region. Surveyed consumers were very confident and aware of certain micro locations and were in favour of micro locations (terroir).

Through cluster analysis two clusters were differentiated upon three composite measures. Considering wine attributes for autochthonous wines, as segmentation criteria, origin played the most important role. Origin distinguished segments of wine consumers, suggesting that wine exhibitions focused on promoting autochthonous wines accomplished their goals.

The relationship between wine consumption motives and wine attributes by linking segments of wine consumers and their wine consumption motives with miscellaneous 
intrinsic and extrinsic wine attributes was surveyed by numerous authors (Brunner and Siegrist 2011, Bruwer et al. 2002, Fotopoulos et al. 2003, Liu and Murphy, 2007). Our survey confirmed their findings (through logistic regression) and adds an additional contribution because this relationship was tested in the context of autochthonous wine Malvazija Istarska.

Our third hypothesis was confirmed since all findings considered, wine consumption motives were connected to wine attributes. Generally speaking, utilitarian (health and taste) and hedonic reasons (self-expression) were generally major wine consumption motives, while purely symbolic reason like self-indulgence may be perceived as somewhat less important or motives important in certain occasions.

Finally our research results about wine attributes (origin, quality) could be used in marketing and advertising Malvazija istarska to consumers and tourists which visit Istria (similar to Charters and Ali Knight, 2002). Promotion of Istria as a wine region could be based upon our results on the motivation toward the wine region attributes with its micro locations and terroirs (similar to Hall and Mitchell, 2002). Identified motives of social aspects and healthiness of Malvazija Istarska wine Istria could be be used in promotion of Istria as a hedonic and wellness destination.

\section{Acknowledgements}

The research for this paper was conducted as a part of project financed by IPA Operational Programme Slovenia-Croatia 2007-2013, during the project "MalvasiaTourIstra" in 2014-2015. The main focus of this research was placed on wine and Malvazija Istarska as autochthonous grape and wine.

\section{Conflict of interests}

The authors declare no conflict of interest.

\section{References}

1. Ampuero, O., Villa, N. (2006). Consumers'perception of product packing. Journal of consumers market, 23, 100-112.

2. Benfratello, L., Piacenza, M., Sachetto, S. (2009). Taste or reputation: what drives market prices in the wine industry? Estimation of a hedonic model for Italian premium wines. Applied Economics, 41, 2197-2199.

3. Boudreaux, C.A., Palmer, S.E. (2007). A charming little Cabernet: Effects of wine label design on purchase intent and brand personality. International Journal of Wine Business Research, 19(3), 170 - 186.

4. Brunner, T.A., Siegrist, M. (2011). A consumer-oriented segmentation study in the Swiss wine market. British Food Journal, 113(3), 353 - 373.

5. Bruwer, J., Li E., Reid, M. (2002). Segmentation of the Australian Wine Market Using a Wine-Related Lifestyle Approach. Journal of Wine Research, 13(3), 217-242. 
6. Cardebat, J.M., Fiquet, J.M. (2009). Estimation of a hedonic price equation for Alsace Beaujolas and Provence wines. Applied Economics, 16(7-9), 921-927.

7. Cardebat, J.M., Fiquet, J.M. (2013). Expert opinions and Bordeaux wine prices: an attempt to correct the bias of subjective judgments, AAWE Working Paper 129, http://www,wine-economics,org/list-of-aawe-working-papers/

8. Celhay, F., Remaud, H. (2016). What does your wine label means to consumers? A semiotic approach. $9^{\text {th }}$ Academy of wine business research conference, Conference proceedings, 381-387.

9. Charters, S. (2006). Wine and Society, Elsevier Butterworth-Heinemann, Oxford. ISBN 10:0750666352.

10. Charters, S., Ali-Knight, J. (2002). Who is the wine tourist? Tourism management, 23(3), 311-319.

11. Chrea, C., Melo, de L., Evans, G., Forde, C., Delahunty, C., Cox, D.N. (2011). An investigation using three approaches to understand the influences of extrinsic product cues on consumer behaviour: An example of Australian wines. Journal of Sensory Studies, 23, 13-24.

12. Chrysochou, P., Jorgensen, J.B. (2016). Danish consumer preferences for wine and the impact of involvement. $9^{\text {th }}$ Academy of wine business research conference, Conference proceedings, 194-202.

13. Combris, P., Bazoche, P., Giraud-Heraud, E., Issanchou, S. (2009). Food choices: What do we learn from combining sensory and economic experiments? Food quality and Preference, 20(8), 550-557.

14. Corduas, M., Cinquanta, L., Ievoli, C. (2013). The importance of wine attributes for purchase decisions: A study of Italian consumers' perception. Food Quality and Preference, 28, 407-418.

15. DiStefano, C., Zhu, M., Mîndrilă, D. (2009). Understanding and Using Factor Scores: Considerations for the Applied Research. Practical Assessment Research \& Evaluation, 14(20), 1-11.

16. Duarte, F., Madeira, J., Barreira, M. (2010). Wine purchase and consumption in Portugal - an exploratory analysis of young adults' motives/attitudes and purchase attributes. Ciência Téc, Vitiv, 25(2), 63-73.

17. Eldesonky, A., Mesias, F. (2014). An insight into the influence of packaging and presentation format on consumer purchasing attributes towards a cheese: a qualitative study. Spanish Journal of Agricultural Research, 12(2), 305-312.

18. Festival Malvazija, http://www.malvazija.info/festival.html (reached at 12, September 2018)

19. Field, A. (2005). Discovering Statistics Using SPSS, Sage Publication Ltd: London, UK, 1-816. ISBN 978-1-84787-906-6.

20. Fotopoulos, C., Krystallis, A., Ness, M. (2003). Wine produced by organic grapes in Greece: using means - end chains analysis to reveal organic buyers' 
purchasing motives in comparison to the non-buyers. Food Quality and Preference, 14(7), 549-566.

21. Foxall, G.R., Goldsmith, R.E. (1994). Consumer psychology for marketing. Routledge, Oxford, UK, 1-244, ISBN 0415046742.

22. Frankel, J., Rose, A. (2010). Determinants of Agricultural and Mineral Commodity Prices. Research Working Paper Series, 10-038, JF, Kennedy School of Government, Harward University, USA.

23. Gomez, M., Molivia, A., Esteban, A. (2013). What are the main factors attracting visitors to wineries? A PLS multi group comparison. Quality and Quantity, 47, 2637-2657.

24. Goodman, S., Lockshin, L., Remaud, H. (2010). Where to shop? The influence of store chracteristics on retail segmenation. Auckland $5^{\text {th }}$ International "Academy of wine business research conference, http://academyofwinebusiness,com/wp content/uploads/2016/03/Conference-Proceedings-Final_TOC_Final.pdf

25. Hair, J.F., Black, W.C., Babin, B.J., Anderson, A.E. (2014). Multivariate Data Analysis. Pearson Education Limited, Harlow, Essex, UK, 1-729, ISBN 10:1292-02190-X.

26. Hall, C.M., Mitchell, R.D. (2002). The tourists' terroir of New Zealand wine: The importance of region in the tourism experience. Food and Environment: Geographies of taste, 69-91.

27. Hall, J., Lockshin, L., O’ Mahony, G.B. (2001). Exploring the Links Between Wine Choice and Dining Occasions: Factors of Influence, International Journal of Wine Marketing, 13 (1), 36-53.

28. Hall, J., Shaw, M., Doole. I. (1997). Cross-cultural Analysis of Wine Consumption Motivations. International Journal of Wine Marketing, 9(2), 83-92.

29. Hertzberg, H., Malorgio, G. 2008. Wine demand in Italy: an analysis of consumer preferences. New Medit, 4, 40-46.

30. Hinkin, T.R., Tracey, J.B., Enz C.A. (1997). Scale Construction: Developing Reliable and Valid Measurement Instruments. Journal of Hospitality \& Tourism Research, 21(1), 100-120.

31. Hughson, A., Ashman, H., De la Huega, V., Moscowitz, H. (2004). Mind set of the wine consumer. Journal of Sensory Studies, 19, 85-105.

32. Ilak Peršuric, A.S., Težak, A. (2011). Wine production on Istria family farms, Acta agriculturae Slovenica, 97(1), 25-31.

33. Ilak Peršurić, A.S., Težak Damijanić, A., Saftić, D. (2016). Winery and wine exhibition visitors' characteristics in the context of wine tourism development New Medit, 4, 82-89.

34. Jarvis, W., Rungie, C., Lockshin, L. (2007). Revealed preference analysis of red wine attribute using polarisation. International Journal of Wine business research 19(2), 127-138. 
35. Jouvier, A.J.V., Montes, F.J.L., Fuentes, M.D.M.F. (2004). Measuring perception of quality in food products: The case of red wine. Food Quality and preference, 15, 453-469.

36. Kallas, Z., Escobar, C., Gill, J. (2012). Assessing the impact of Christmas advertisement campaign on Catalan wine preference using choice experiments. Appetite, 52, 258-298.

37. Koch, J., Martin, A., Nash, R. (2013). Overview of perceptions of German wine tourism from the winery perspective. International Journal of wine Business Research 25(1), 50-74.

38. Liu, F., Murphy, J. (2007). A qualitative study of Chinese wine consumption and purchasing: Implications for Australian wines. International Journal of Wine Business Research, 19(2), 98 - 113.

39. Lockshin, L., Jarwis, W., d'Hautville, F., Perrouty, J.P. (2006). Using simulations from discrete choice experiments to measure consumers sensitivity to brand, region, price and awards in wine choice. Food quality and preference, 17, 166178.

40. Lopes, P., Sagala, R., Lockshin, L. (2016). Importance of eco-logo and closure type on consumer expectations, price perception and willingness to purchase wines in Canada. AAWE working paper 200, http://www.wineeconomics.org/ aawe/wpcontent/uploads/2016/07/AAWE WP200.pdf

41. MacDonald, J.B., Saliba, A.J., Bruwer, J. (2013). Wine choice and drivers of consumption explored in relation to generational cohorts and methodology, Journal of Retailing and Consumer Services, 20, 349-357.

42. Marzo-Navarro, M., Iglessias, M.P. (2012). Critical factors of wine tourism: incentives and barriers from the potential tourist's perspective, International Journal of contemporary Hospitality Management 24(2), 312-334.

43. Matos Graça Ramos, P., Martins, F.V., Gouveia Barandas, H. (2011). Differences in the Perception of Wine Attributes: A Comparative View Between Consumers, Producers and Intermediaries. Bulletin de l'OIV, 84, 271-306.

44. Melo, L., Colin, J., Delahunty, C., Forde, C., Cox, D.N. (2010). Lifetime wine drinking, changing attitudes and associations with current wine consumption: A pilot study indicating how experience may drive current behaviour. Food quality and Preference, 21, 784-790.

45. Outreville, F.J. (2011). Does the bottle size matter? An investigation into differences between posted and market price. AAWE Working Paper 86, http:// www,wine-economics,org/list-of-aawe-working-papers/

46. Quester, P.G., Smart, J. (1996). Product Involvement in Consumer Wine Purchases: Its Demographic Determinants and Influence on Choice Attributes. International Journal of Wine Marketing, 8(3), 37 - 56.

47. Ramos, P.M.G., Martins, F.V., Barandas, H.G. (2011). Differences in the 
Perception of Wine Attributes: A Comparative View Between Consumers, Producers and Intermediaries. Bulletin de l'OIV, 84, 271-306.

48. Roma, P., Di Martino, G., Perrone, G. (2013). What to show on wine labels: a hedonic analysis of price drivers of Sicilian wines. Applied Economics, 45(19), 2765-2778.

49. Rössel, J., Beckert, J. (2012). Quality classification in competition: Price formation in the German Wine market, AAWE Working Paper 114, http://www. wine-economics.org/list-of-aawe-working-papers/

50. Ružić, P., Ilak Peršurić, A.S., Milohanović, A. (2006). The impact of consumer preferences on Istrian Malvasia wine consumption. Rivista di viticoltura e di enologia 59 (2-3), 99-110.

51. Schultz, F.R. (2015). Word of mouth impulses: Evidence from wines of Germany, AAWE Working paper 187, http://www.wine-economics.org/list-ofaawe-working-papers/

52. Sinclair-Maragha, G., Gursoyb, D., Viereggec, M. (2015). Residents' Perceptions toward Tourism Development: A Factor-cluster Approach, Journal of Destination Marketing \& Management, 4(1), 36-45.

53. Težak, A., Šergo, Z., Uravić, L. (2009). Wine in tourism - tourist destination Istria, Planning for the Future - Learning from the Past, Proceedings 4th International Tourism Conference, 56-62.

54. Veal A.J. (2006). Research Methods for Leisure and Tourism: A Practical Guide. Pearson Education Limited: Essex, 1-559, ISBN 0273682008.

55. Verdonk, N.R., Wilkinson, J.W., Culbert, J.A., Ristić, R., Lane, M.J., Pearce K.L., Wilkinson, K.L. (2016). Australian consumers perceptions of Champagne and other sparkling wine: and exploratory study, Conference proceedings $9^{\text {th }}$ Academy of wine business research conference, 184-193.

56. Vinistra, 2018, www.vinistra.com (reached at 12, September 2018)

57. Yuang, J., Jang, S. (2008). The effects of quality and satisfaction on awareness and behavioural intentions: Exploring the role of a wine festival. Journal of Travel Research, 46, 279-228. 